\title{
The Contribution of Students' Linguistic Intelligence Towards Reading Comprehension
}

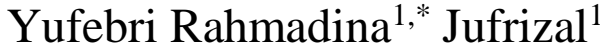 \\ ${ }^{1}$ Universitas Negeri Padang, Padang, Indonesia \\ *Corresponding author. Email: yufebri.rahmadina@gmail.com
}

\begin{abstract}
Linguistic intelligence is the students' ability in using words in speaking and writing. It becomes one of the important factors that influence the students' reading comprehension, because it is related with individual's intelligence in understanding a language. This study is aimed to find out the contribution of students' linguistic intelligence toward reading comprehension. This study was document analysis and the data were analyzed descriptively. As a result of this study, it was found that the students' linguistic intelligence gave significant contribution toward reading comprehension. These data were analyzed by the researcher from some qualified journals. It also found that there were some characteristics of the students who have dominant linguistic intelligence. Moreover, the students' linguistic intelligence cannot be ignored because it was indicated as a strong predictor of the students' reading comprehension. It also showed that the students with well-developed of linguistic intelligence showed interest in reading activity that reflected to their reading comprehension.
\end{abstract}

\section{Keywords: Contribution, Linguistic Intelligence, Reading Comprehension}

\section{INTRODUCTION}

Reading is the process of acquiring the meaning and information that is presented in written forms. Through reading the students get knowledge about what they read. It makes reading becomes one of the crucial skills in learning a language because the students will read the text every day in their daily life, for instance in learning process they will read the textbook and take the test that is in written text. In addition, the students need to have good reading comprehension because it is the way of understanding the meaning of the text. It is supported by Moore et al. [1] who state that reading comprehension is one of the fundamental skill that needs the process of constructing the meaning of written text. Therefore, it can be said that reading is the activity that is done by the individuals in order to understand the text that they read.

Moreover, the students who have good knowledge might get the meaning and information of the text easily. This idea is supported by Nunan [2] who says that the goal of reading is the individuals' comprehension of the text. It can be inferred that in reading activity the students should not only reading the text, but they also should get the meaning of the text that they read. In addition, through reading comprehension, the students will get knowledge because the more they read the more they know about something they do not know before. Thus, it can be said that the students' knowledge is also related with their success in reading comprehension.
Additionally, there are some factors that might give contribution toward students' reading comprehension. One of the factors is the students' linguistic intelligence. It is one of Gardner's multiple intelligence types. According to Halil [3] linguistic intelligence is the individuals' intelligence type that is related and connected with their ability in understanding a language.In line with this theory, it means that linguistic intelligence is one of the individual's intelligence type that focus on the ability in using and expressing the language.

Linguistic intelligence is related to a language where the students can receive the meaning of spoken and written words easier and understand it clearly. It is one of Gardner's multiple intelligence type that have been concern for the educators, because it is assumed that linguistic intelligence to be the most significant factor in understanding a language. In other words, the students have different intelligence in learning process including their abilities in reading, so that the educators should not prevent this type of intelligence because linguistic intelligence might give a strong contribution to the students' reading comprehension. Furthermore, linguistic intelligence can help the students to understand the information of the text. Besides, Fleetham [4] also mentions that linguistic intelligence is the ability in thinking and using the language effectively. It means that linguistic intelligence can be seen by the ways the students using the language correctly such as their ability in expressing and getting the meaning of the language whether it's in spoken or written forms. 
However, Armstrong [5] mentions that linguistic intelligence also involves the ability of using the syntax, semantics, phonology, and pragmatic dimensions of the language. In line with the theory above, it can be said that linguistic intelligence also involves the students' ability in understanding the language forms and how they apply it in their real life specifically in learning a language. Moreover, all of those language forms are very crucial because the syntax, semantics, phonology and pragmatic are really needed in learning a language.

In addition, the students' linguistic intelligence can be seen through their characteristics in language learning. It is supported by Laughin in Erlina et al. [6] who states that the person who has well-developed linguistic intelligence can be seen through their listening and reacting toward the sound, rythm, learning by listening, reading, writing and discussion. Based on the theory above, it means that linguistic intelligence also involves the students' ability in understanding, paraphrasing, interpreting and remembering what has been said and read. It also said that linguistic intelligence involves the ability in communication and persuade others. Then, it can be inferred that the students who have well-developed linguistic intelligence probably will be successful in learning a language including their ability in reading comprehension, because they can use the language effectively in speaking, listening, reading and writing.

Furthermore, Mujiono et al. [7] mentions that linguistic intelligence involves of the ability in using a language to express the complex meanings that involves understanding the order and meaning of words in spoken and written. This theory is quite similar with both previous theories, because it explains that linguistic intelligence can be seen through how the students understand the meaning of words orally and written.It means that linguistic intelligence is also related with the students' reading ability such as how they comprehend the text. Then, if the students can get the meaning of the text easily, probably they might have good reading comprehension. Therefore, if the students try to improve their linguistic intelligence then their reading comprehension might be increased too, because linguistic intelligence is related with the students' ability in using and understanding a language.

Then, according to Armstrong's theory [8] there are some activities that reflected the students' linguistic intelligence. First, the students become conscious about the sounds of language. Second, they have communication skills such as they like to tell stories. Third, they can interpret the language that they listen or read also they can remember words or vocabulary. Then, the students are aware about the grammatical of the language. Last, they are interested in playing a game that related with words and they also like poetry. Based on those characteristics, the researcher will see the dominant characteristics of students' linguistic intelligence in reading class. This theory explains some activities that reflect on the students' linguistic intelligence. Moreover, linguistic intelligence also involves the students' awareness about the meaning of the words and the language function. Gardner [9] states that people who have linguistic intelligence can be seen from their sensitivity to the patterns, systematic basis, arguing, listening, reading, writing, spelling the words easily, playing the word, has sharp memories and doing well in public speaking. It can be said that the students who have dominant linguistic intelligence are interested and probably doing well in speaking, listening, reading and writing.

Therefore, the students should pay more attention about their linguistic intelligence, because it might be a strong predictor of the students' successful in language learning including reading comprehension. However, linguistic intelligence is important to be studied because according to Alhamudin and Bukhrori [10] linguistic intelligence plays important role in learning process and it affects the students' achievement in learning. It can be said that the students should have dominant linguistic intelligence in order to help them learning a language. Moreover, it is a new thing related with the previous studies that most of them have discussed about the relationship of multiple intelligence toward the students' reading comprehension. For example, Mesbah et al. [11] conducted a study about the relationship of the students' multiple intelligence and reading comprehension. Then, the study that was conducted by Masoud [12] that they also investigate the relationship of multiple intelligence toward L2 leaners' reading ability. Then, only few studies that have discussed about the contribution of students' linguistic intelligence toward reading comprehension in specific. Unfortunately, there were still many students who did not know about their linguistic intelligence. Also, in learning process it still found that some students were not using the language effectively [6].

Thus, this study had a purpose to find out the contribution of students' linguistic intelligence toward reading comprehension. In addition, the researcher not only analyze the Indonesian students' linguistic but also the researcher wanted to analyze the Iranian students' linguistic intelligence as EFL learners. Besides, the data were collected from some journals that focused on the students' linguistic intelligence in reading activity. Then, the researcher also wants to find out some indicators of students' linguistic intelligence that is reflected from their characteristics in language learning specifically in reading activity. Therefore, this research focused to find out how was the contribution of students' linguistic intelligence toward reading comprehension. Through this research, the researcher also want to find out what are the dominant characteristics of the students' linguistic intelligence in reading class.

\section{METHOD}

This research used descriptive research, because in this research the researcher wants to describe and interpret the data. In addition, the data of this research were collected from the documents. The reasons why the researcher used document analysis because it was the effective and useful way in gathering the data. In this case, the type of documents that was used in this research was some qualified journals that focused on the students' linguistic 
intelligence in reading comprehension. Then, there are some journals that became the sources of data for this research it can be seen as follow.

a. First study that was conducted by Mujiono et al. (2019) entitled The Effect of Verbal Linguistic Intelligence and Emotional Intelligence on Academic Achievement of Indonesian EFL Learners.

b. Second study that was conducted by Rahimi et al. (2011) entitled The Impact of Linguistic and Emotional Intelligence on The Reading Performance of Iranian EFL Learners.

c. Third study that was conducted by Dewi (2019) entitled Linguistic intelligence, Vocabulary Knowledge, and Students Reading Comprehension.

d. Forth study that was conducted by Dewi and Wilany (2019) entitled The Relationship between Verbal Linguistic Intelligence and Reading Comprehension.

e. Fifth study that was conducted by Aulia and Nuardi (2018) entitled The Correlation between Students' Linguistic Intelligence and Reading Comprehension.

f. Sixth study that was conducted by Hasanudin and Fitrianingsih (2019) entitled Verbal Linguistic Intelligence of the First-Year Students of Indonesian Education Program: A Case in Reading Subject.

g. Seventh study that was conducted by Erlina et al. (2019) entitled Linguistic Intelligence under Graduate EFL Learners in Higher Education: A Case Study.

h. Eighth study that was conducted by Reza and Tabrizi (2016) entitled Multiple Intelligence and EFL Learners' Reading Comprehension.

Therefore, the researcher identified the data from different background of learners that was from Indonesian and Iranian learners which learnt English as foreign language. These data were analyzed with the aim of getting the information about how was the contribution of the students' linguistic intelligence toward reading comprehension. Thus, this research also provided some indicators of students' linguistic intelligence and the dominant characteristics of the students' linguistic intelligence in reading activity.

\section{RESULT AND DISCUSSION}

After analyzing some qualified journals as the data of this research, the researcher found some results as follow.

First, Mujiono et al. [7] found that there was significant correlation between linguistic intelligence and the students' academic achievement. It was proven by the result of the correlation coefficient was 0.662 which means there was a quiet strong relation between students' linguistic intelligence and academic achievement. The participant of this study was English Education department students. It also found that linguistic intelligence gave strong effect on students' English skills including reading comprehension, it can be seen from the data that linguistic intelligence gave $44 \%$ effect on academic achievement. Moreover, the writers also found that emotional intelligence showed a weak effect on the students' achievement rather than linguistic intelligence. It can be said that linguistic intelligence gave significant contributed toward students' achievement in English including reading comprehension. Actually, many studies also indicated the same results of this study, specifically in reading comprehension. In other words, the students' linguistic intelligence more gave contribution toward students' academic achievement than emotional intelligence.

Second, Rahimi et al. [13] reported that linguistic intelligence became a strong predictor of students' reading comprehension. Then, the participant of this study was 90 Iranian students who took English major. Practically speaking, it also noted that linguistic intelligence was related with the students' cognition which was involved in their successful in reading comprehension. It also found that linguistic intelligence predicted the students' reading performance because intelligence and cognition are part of comprehension. It means that linguistic intelligence is very essential in language learning because it is involved in reading activity. As it was discussed above, it is important for the teacher to make the classroom activity that is more involved the students' linguistic intelligence so that they can improve their ability in using language.

Third, the study that was conducted by Dewi [14], it showed that linguistic intelligence gave positive influence on students 'reading comprehension. Besides, the participant of this study was 283 Indonesian students at Madrasah Pembangunan, Jakarta. From this study, it claimed that the students who had good linguistic intelligence tended to had a good reading comprehension, because English language variable of linguistic intelligence gave contribution in improving the students' reading comprehension ability. It was related with the previous study that linguistic intelligence became one of the factor that can predict the students' successfull in learning a language because it involved the students' cognitive process.

In addition, it also found some indicators of students' linguistic intelligence in reading activity. First, the students loved to read. Second, the students often spoke what they have read. Third, they were good at spelling patterns. Next, they liked playing word games and poems. Then, the students can keep their book collection. Also, they can remember general knowledge, quotes and words easily. Next, they can explain and interpreting what they have read easily. Last, the students had good knowledge about language use. Based on those indicators, it can be said that the students who have dominant linguistic intelligence have tendency to have good reading comprehension. In other words, by having a good linguistic intelligence, it can increase the students' ability in reading, because they understand what they have read easily. Practically speaking, the students and the teacher should be aware about linguistic intelligence. Thus, they can change their learning habit and learning style that is appropriate with their intelligence, so that their linguistic 
intelligence can be improved. Therefore, the teacher can create new ideas in teaching learning process, and choosing the appropriate teaching material that fit with the students' linguistic intelligence.

Forth, Dewi and Wilany [15] attempted that there was a significant correlation between linguistic intelligence and reading comprehension, it was shown from the $r$ count was 0.68 which means that linguistic intelligence gave positive influence toward reading comprehension. Moreover, the writer also explained that the students' linguistic intelligence can be seen through some following indicators. First, he students can write a story or essay about their daily experience. Second, they can express their ideas clearly. Third, the students had rich vocabulary. Forth, the students enjoy in reading many kind of the text such as book, newspaper, magazine, etc. Fifth, the students can spell the words in foreign language easily. Sixth, they liked listening to a story. Seventh, they can do a storytelling. It can be inferred that the students' linguistic intelligence can be seen by their interest in using a language. Besides, in learning process, it is crucial to use the appropriate strategy based on the students' linguistic intelligence in order to achieve good reading comprehension, because linguistic intelligence can reflect the students' successful in reading comprehension.

Fifth, Aulia and Nuardi [16] found that there was significant correlation between the students' linguistic intelligence and reading comprehension with the data showed that $45,6 \%$ of the students' reading comprehension was influenced by the students' linguistic intelligence which means linguistic intelligence have contributed toward reading comprehension. Then, the participant of this study was 55 Indonesian students. It also mentioned that the students' reading comprehension will be improved if their linguistic intelligence increased. As it was discussed above, the students' reading comprehension can be improved if they develop their linguistic intelligence because it can help them in using the language effectively. Thus, it is important for the students to develop their linguistic intelligence by following some activities that related with language learning, for example, by reading a lot, writing a story and re-tell the story, also playing the words games.

Sixth, Hasanudin and Fitrianingsih [17] found that that there were some indicators of linguistic intelligence of students in reading subject. First, the students had excellent knowledge in mentioning words, such as they can express the words in his mind just by reading the title of the books. Second, the students were enjoying wordplay. For example in doing the scrabble games, they can answer the questions and arrange the words correctly. Third, they can explain the meaning of the words that they have read and discussed it. Forth, most students were having difficulties in mathematics lesson, they prefer English, social, and history lesson than mathematics. Thus, the data showed that they only answered the mathematics questions randomly; because it was difficult for them, they also prefer reading short stories. Fifth, in doing the conversation, they used some words that related to something they have read and heard before such as the words that they had heard from their classmates and the words that they had read from articles. Sixth, the students had the ability in writing the poetry based on their personal experience. In line with the findings above, the indicators of linguistic intelligence can be seen through the students' characteristics in learning process. Therefore, it can be inferred that the students who have good linguistic intelligence tend to have creative thinking because they can write poem and read it in front of their classmates.

In contrast, based on Erlina et al. [6] it was found that there was a minimum number of students who had dominant linguistic intelligence on their study. Besides, the participant of this study was 28 Indonesian undergraduate students also the writers mentioned that the aim of this study was not for generalization, but the result of this study was shown by phenomena in learning a language. The result showed some aspects of the students' linguistic intelligence. First aspect is rhetoric that is the ability in using the language effectively to persuade others [8]. However, the result showed that only 3 of 28 students who used the language effectively to persuade others. For instance, some students had lack of linguistic factors in persuading others and delivering their ideas in spoken and written forms. Second aspect is mnemonic that is the ability in memorizing the information [8]. It was found only 2 of 28 students who can remember and retell the information or the story of the text that they have read. Third aspect is explanation that is the ability in delivering the information orally and written [8]. It was found that the students still face difficulties in using descriptive and figurative language in order to deliver their ideas, also only one student who used it well when she wrote a poem. Forth aspect is metalinguistic that is the ability in learning the language itself [8]. It showed that in reading class the students were active participate in asking the questions about the words that they did not familiar. From the result, it can be seen that in reading activity the students still had the curiosity in learning a language even though they still faced difficulties in delivering their thoughts in spoken and written forms.

Last, Reza and Tabrizi [18] found that linguistic intelligence was the most significant predictor of the students' reading comprehension among the multiple intelligences types. It also found that the students with high linguistic intelligence were able to use the language effectively that they were typically good at reading, playing word games; memorize words, storytelling, and making poetry. In line with the finding, Hashemi [19] also attemped that linguistic intelligence made the strongest contribution in predicting the students' reading comprehension. In other words, the students should not ignore this type of intelligence because it influences their reading comprehension. In fact, the students still not aware about their linguistic intelligence. However, it is crucial for the teacher to give the chance for the students to develop their linguistic intelligence in classroom, for instance by creating a learning strategy that related with playing word games and story telling that involves the students' ability in using a language. It is also supported by Gardner in Arnold and Fonseca [20] who states that it is 
important to know and develop the individuals' different types of intelligence including linguistic intelligence because all of the individuals are different to each other that they have the combinations of intelligence. Therefore, based on the results of this research, it found that students' linguistic intelligence gave significant contribution toward reading comprehension. Hence, the students should give more attention toward their linguistic intelligence because it helps them to improve their ability in reading.

\section{CONCLUSIONS}

In conclusion, linguistic intelligence is the students' ability in using the language whether in spoken or written forms. Then, based on the results of this research, linguistic intelligence gave significant contribution toward students' reading comprehension. It was shown from the data that more than $45 \%$ of students' reading comprehension was influenced by their linguistic intelligence, and it also showed positive correlation between the students' linguistic intelligence and reading comprehension. Then, the students with well-developed linguistic intelligence can achieve a good reading comprehension because they like the activity that involves their ability in using language. In other words, it is crucial for the students to be aware about their linguistic intelligence because they have a tendency to have a good reading comprehension score.

Moreover, it also found that there were some dominant characteristics of the students' linguistic intelligence in reading activity. First characteristic is they had knowledge about the text that they read. Next, the students enjoyed playing word games and wrote their own story and poem. Then, the students can convey and retell the story or the text and they can remember about the text that they read. However, even though there were some students who did not have dominant linguistic intelligence, but they still had the motivation and interested in learning a language.

\section{ACKNOWLEDGMENT}

The writer expresses the deepest gratitude to her parents, sister and friends who have given their support and motivation. Then, this study would not have been possible without the help of my advisor Prof. Dr. Jufrizal, M.Hum for his advice and guidance. Hopefully, the result of this study will give beneficial impact for education.

\section{REFERENCES}

[1] J. J. Moore, D. Ph, E. C. Alef, and E. D. Vogel, "The Simplicity and Complexity of Reading Comprehension," vol. 7 , no. 6 , pp. 20-26, 2016.

[2] D. Nunan, T. D. Terrell, and H. D. Brown, When ordering this title, use ISBN 007-123462-4, vol. 57, no. 3. 1981.

[3] N. I. Halil, "The Actualization of Literary Learning Model Based on Verbal-Linguistic Intelligence," Int. J. Educ. Lit. Stud., vol. 5, no. 4, p. 42, 2017, doi: 10.7575/aiac.ijels.v.5n.4p.42.
[4] M. Fleetham, "Multiple Intelegnces in Practice enhacing self-esteem and learing in the classroom," 2006.

[5] T. Armstrong, The Multiple Intelligences of Reading and Writing. Virginia USA: Association for Supervision and Curriculum Development (ASCD), 2003.

[6] D. Erlina et al., "Linguistic intelligence of undergraduate EFL learners in higher education: A case study," Univers. J. Educ. Res., vol. 7, no. 10, pp. 2143 2155, 2019, doi: 10.13189/ujer.2019.071012.

[7] Mujiono, Nakhrowi, and S. Fatimah, "The effect of verbal-linguistic intelligence and emotional intelligence on academic achievement of Indonesian EFL learners," Int. J. Learn. Teach. Educ. Res., vol. 18, no. 12, pp. 350-365, 2019, doi: 10.26803/ijlter.18.12.20.

[8] T. Armstrong, Multiple Intelligences in the Classroom, 3rd ed., vol. 124, no. 1. United States of America, 2009.

[9] H. Gardner, "Intelligence reframed: Multiple intelligences for the 21st century," vol. 16, no. 2, pp. 131133, 1999, doi: 10.1080/15332276.2001.11672976.

[10] A. Alhamuddin and B. Bukhori, "The Effect of Multiple Intelligence-Based Instruction on Critical Thinking of Full Day Islamic Elementary Schools Students," Ta'dib, vol. 21, no. 1, p. 31, 2016, doi: 10.19109/td.v21i1.590.

[11] D. Mojgan Mesbah, Mesbah, M, S Zeraatian, D. Hosseini, M., Naseripour, M. and , 5Pazooki, "the Relationship Between Multiple Intelligences and Reading Comprehension," International Journal of Development Research, vol. 08, no. 04, 2018. ISSN: 2230-9926.

[12] M. M. K. Masoud Khalili Sabet, "The Relationship between Multiple Intelligences and Reading Comprehension of EFL Learners across Genders," Int. J. Educ. Lit. Stud., vol. 4, no. 1, 2016, doi: 10.7575/aiac.ijels.v.4n.1p.74.

[13] M. Rahimi, F. Sadighi, and Z. Hosseiny Fard, "The impact of linguistic and emotional intelligence on the reading performance of Iranian EFL learners," J. Teach. Lang. Ski., vol. 30, no. 1, pp. 151-171, 2012.

[14] S. R. Dewi, Linguistic Intelligence, Vocabulary Knowledge, and Students 'Reading Comprehension Faculty of Education Sciences. 2019.

[15] D. S. Dewi and E. Wilany, "Hubungan Antara Kecerdasan Linguistik Verbal Dan Kemampuan Membaca," J. Dimens., vol. 8, no. 1, pp. 187-197, 2019, doi: 10.33373/dms.v8i1.1859.

[16] N. Aulia Nugraheni, "The Correlation between the Students' Linguistic Intelligence and Reading 
Comprehension," Indonesian Journal of Integrated

English Language Teaching, vol. 4, no. 1, pp. 1-15, 2018.

[17] C. Hasanudin and A. Fitrianingsih, "Verbal linguistic intelligence of the first-year students of Indonesian education program: A case in reading subject," Eur. $J$. Educ. Res., vol. 9, no. 1, pp. 117-128, 2020, doi:

10.12973/eu-jer.9.1.117.

[18] A. Reza and N. Tabrizi, "Multiple Intelligence and EFL Learners' Reading Comprehension,"

Elt.Tabrizu.Ac.Ir, vol. 18, no. 18, 2016.

[19] A. Hashemi, "The Relationship between Multiple Intelligences and Reading Comprehension," Andishah va Raftar, vol. 2, no. 6, 2008.

[20] J. Arnold and M. C. Fonseca, "Multiple Intelligence Theory and Foreign Language Learning:a Brain-Based Perspective," Int. J. English Stud., vol. 4, no. 1, pp. 119136, 2009. 